\title{
APRESENTAÇÃO
}

A publicação deste número da revista Working Papers em Lingüística (WPL), uma das revistas científicas do Programa de Pós-Graduação em Lingüística da UFSC, tem um significado muito especial, que é a passagem da revista da versão impressa para a versão on-line. Para que a revista chegasse a esse estágio, houve todo um trabalho árduo, não-visível ao leitor, que foi a digitalização de todos os seus números impressos. Digitalizar esse acervo, uma das exigências para a entrada no Portal de Periódicos da UFSC (http://www.periodicos.ufsc.br/), atende também a uma série de objetivos da WPL, dentre os quais destaco manter a história das publicações dos números impressos e torná-los disponíveis on-line para os leitores, pois, hoje, com as novas tecnologias, o maior meio de acesso às publicações científicas é, sem dúvida, a internet.

A digitalização do acervo impresso da revista, em especial, e a publicação deste primeiro número on-line contaram com o apoio de colegas a quem a revista dedica um agradecimento muito especial, pois deve a eles o sucesso de sua transição: a Professora Dr ${ }^{a}$ Ursula Blattmann, da área de Biblioteconomia e Ciência da Informação da UFSC e uma das professoras responsáveis pelo Portal de Periódicos da UFSC, que sempre auxiliou a equipe editorial em todos os passos da digitalização do acervo impresso e da publicação do primeiro número on-line, bem como disponibilizou uma de suas bolsistas para realizar a digitalização desses números impressos e sua inclusão na plataforma da revista; e a bolsista Sirlene Pintro, responsável pela digitalização do acervo e sua inclusão no arquivo on-line da revista, duas atividades extensas e cansativas, que exigiram um nível apurado de conhecimento e atenção para o sucesso da tarefa.

A migração da revista impressa para a plataforma SEER - Sistema Eletrônico de Editoração -, que abriga hoje as Revistas Científicas do Portal de Periódicos da UFSC, além da visibilidade da produção científica e do livre e amplo acesso aos textos por parte dos leitores, permite que se tenha um processo de editoração, embora difícil e minucioso, extremamente confiável, metódico, imparcial na avaliação, explícito em seus critérios e, acima de tudo, ágil na publicação dos textos. Se, no mercado financeiro, tempo é dinheiro, na ciência, hoje, tempo é difusão do conhecimento.

É preciso registrar que a revista, agora no meio on-line, mantém, como foco editorial, a publicação de textos que provêm de diversos campos do conhecimento cujo interesse é a linguagem, em especial daqueles que são contemplados pelas linhas de pesquisa do Programa de Pós-Graduação em Lingüística da UFSC; ou seja, essencialmente, a revista publica resultados de projetos de pesquisa do Programa, o que significa textos de autores externos ao Programa, de professores e alunos do Programa, bem como de alunos de graduação, desde que em co-autoria com o professor responsável pelo processo da pesquisa. 
Nessa linha editorial de publicação, a revista, atendendo a todas as exigências de uma publicação científica internacional (avaliação por pares e "às cegas”, por exemplo), quer ser também uma "incubadora" de novos pesquisadores, por meio do estímulo à publicação de seus pós-graduandos. Com a avaliação e a classificação das revistas pela CAPES, por meio do Qualis de periódicos, as revistas estão cada vez mais restringindo a publicação de pesquisas de doutorandos e, em especial, de mestrandos. Assim, cria-se a contradição de exigir que novos pesquisadores publiquem, mas num campo editorial que cada vez mais se fecha às suas publicações. Visando à inclusão desses novos pesquisadores na comunidade científica, a WPL estimula e incentiva doutorandos, mestrandos e, inclusive, graduandos a submeterem seus textos à revista.

Por último, gostaria de registrar uma decisão da equipe editorial, avalizada pelo Colegiado do Programa, talvez pioneira no campo das publicações científicas, mas que se mostrou bastante eficaz no processo de avaliação dos textos. Como o Programa de Pós-Graduação em Lingüística tem como uma de suas metas alavancar e acompanhar a vida profissional de seus egressos, na avaliação dos artigos por pares, fez-se a experiência de colocar ao lado de um avaliador experiente uma avaliador "novato”, egresso do Programa, com vistas a inseri-lo no campo da avaliação das publicações científicas, uma vez que, normalmente, a escolha dos avaliadores e, em especial da composição do conselho editorial das revistas, segue o critério da notoriedade e experiência do pesquisador. Contrariando essa tradição, a revista ousou introduzir no seu campo de avaliadores jovens pesquisadores. Como essa ação, a WPL, além de ser uma "incubadora" de novos pesquisadores, também assumiu o papel de "incubadora" de avaliadores no campo das publicações científicas.

A análise dessa experiência mostrou que as avaliações realizadas por esses jovens pesquisadores aproximam-se do nível de qualidade daquelas emitidas por avaliadores experientes. Assim, consolidando uma experiência bem sucedida até aqui, a revista optou por compor um conselho editorial que, além de atender aos critérios de diversidade institucional e experiência, também atendesse ao critério de introduzir novos professores, egressos do Programa, nessa atividade científica.

Neste número pioneiro, a WPL apresenta oito textos inéditos: seis artigos e dois ensaios. Os artigos de Ana Paula Kuczmynda Silveira, Nívea Rohling da Silva e Rita de Cássia Fernandes Signor, situados na área da Lingüística Aplicada, têm como núcleo comum a investigação em torno dos gêneros do discurso. O artigo $A$ abordagem do gênero em dois livros didáticos de Língua Portuguesa destinados ao ensino médio, de Ana Paula Kuczmynda Silveira, analisa a apreensão da noção de gêneros em dois livros didáticos do Ensino Médio, focalizando a concepção de gêneros no referencial teórico e metodológico no livro do professor e a elaboração didática dos gêneros nas práticas de leitura, escuta e produção textual no livro do aluno. O artigo Os gêneros do discurso na clínica fonoaudiológica: um estudo de caso, de Rita de Cássia Fernandes Signor, como o título sugere, apresenta um estudo de caso de terapia fonoaudiológica, no campo da apropriação da escrita, que toma como princípio norteador das atividades de escrita, com os pacientes, a teoria de gêneros do Círculo de Bakhtin. Já o artigo de Nívea Rohling da Silva, intitulado $O$ horizonte axiológico do gênero entrevista pinguepongue: uma análise da extensão textual do gênero, por meio da análise de gêneros, demonstra como a extensão textual é uma das marcas dos índices sociais de valor do gênero em questão. 
Os artigos de Ivelã Pereira e Heronides Maurílio Melo Moura, Carine Haupt e Leandra Cristina de Oliveira e Morgana Carina Lenzi e Teresinha de Moraes Brenner situam-se na área da Teoria e Análise Lingüística, sendo que os dois primeiros versam sobre temas do campo da semântica e da pragmática, respectivamente, e o terceiro apresenta resultados de pesquisa no campo da fonologia. O artigo Máquinas e mentes: interpretando a metáfora, de Ivelã Pereira e Heronides Maurílio Melo Moura, por meio da análise de verbos de atitude proposicional usados metaforicamente em relação aos tópicos "máquinas" e "inteligência artificial”, em textos publicados na web, testa a hipótese de que as metáforas possuem uma estrutura léxico-conceptual e de que há sistematicidade na interpretação metafórica conforme a classe verbal (ou nominal) dos veículos das metáforas. $\mathrm{O}$ artigo $A$ intuição de crianças $e$ adultos na interpretação dos numerais: uma questão semântica ou pragmática?, de Carine Haup e Leandra Cristina de Oliveira, a partir de pesquisa teórica e empírica com crianças e adultos, objetiva averiguar a interpretação que os indivíduos fazem dos numerais: se o numeral pode gerar diferentes interpretações conforme o contexto em que ele está inserido e se crianças e adultos interpretam da mesma forma os numerais. Já o artigo de Morgana Carina Lenzi e Teresinha de Moraes Brenner, Análise das vogais postônicas finais [e] e [o] nos falantes do município de Doutor Pedrinho, analisa, por meio de entrevistas com moradores daquela cidade, subdivididos em três grupos em relação à faixa etária, o uso das vogais em posição postônica final e apresenta como resultado que, nessa comunidade, em contexto de sílaba postônica final, há cinco vogais.

Finalmente, a apresentação dos dois ensaios. O ensaio de Atílio Butturi Junior, intitulado Quine e Foucault: ontologia relativista e categorias discursivas, nas palavras do autor, "intenta uma aproximação entre a discussão de relatividade ontológica em Quine e a arqueogenealogia foucauldiana, na tentativa de interrogar acerca da configuração de saber a que estes pertenceriam, diretamente relacionada com o chamado linguistic turn e, não obstante, formulada como resposta às tentativas de formalização radical dos saberes via linguagem”. O ensaio Entre Chomsky e PortRoyal: uma análise da leitura chomskiana, de Fernanda Cizescki, objetiva analisar a interpretação feita por Chomsky, na obra Lingüística Cartesiana e Linguagem $e$ Pensamento, a respeito da presença dos conceitos de estrutura profunda e superficial na Gramática de Port-Royal e demonstrar como essa interpretação influenciou o desenvolvimento do projeto chomskiano na proposta da relação entre linguagem e pensamento.

Para terminar, gostaria de registrar que este número da WPL também foi pioneiro no desbravamento e entendimento dos inúmeros meandros da Plataforma SEER. Assim, meu agradecimento especial a todos os colaboradores desta empreitada, nomeados no expediente da revista: a equipe editorial, os pareceristas deste número e também os autores dos textos publicados.

Desse trabalho coletivo, nasceu este número tão especial para a revista WPL, que entregamos à apreciação de nossos leitores. Boa leitura!

\section{Rosângela Hammes Rodrigues}

\section{Editora}

